\title{
Feeding ecology of a Mediterranean endemic mesopredator living in highly exploited ecosystems
}

\author{
Ethan Coll-Calvo, Claudio Barría, Laura Recasens and Joan Navarro* \\ ${ }^{1}$ Institut de Ciències del Mar - CSIC, Passeig Marítim de la Barceloneta, 37-49, 08003 \\ Barcelona, Spain \\ * Corresponding author: \\ joan@icm.csic.es
}

\begin{abstract}
Knowledge of marine predator trophic ecology is essential for defining their ecological role and trophic position in ecosystems. Based on their trophic habits, sharks and batoids occupy higher and medium trophic levels in the food webs, although differences in the trophic preferences exist between species. They are important organisms in marine ecosystems by maintaining the species below them in the food chain and serving as an indicator for ocean health. In comparison to sharks, batoids usually receive less research attention, with very little diet information available. This is true of the speckled ray (Raja polystigma), one of the three endemic batoids in Mediterranean waters. Here, by combining analyses of stomach contents and stable isotopes, we examined the trophic ecology (dietary composition and trophic position) of this ray in the north-western Mediterranean Sea. We also compared its trophic niche with the trophic position of other sympatric elasmobranchs present in same marine ecosystem. The results revealed that $R$. polystigma mainly consumes shrimps and to a lesser extent crabs, finfish, cephalopods, polychaetes and, surprisingly, small demersal sharks. We also found that $R$. polystigma shows similar trophic position to other crustacean-consumer elasmobranchs such rays and small demersal sharks. The results of this study provide new insights into the ecological role of this endemic ray species in the Mediterranean Sea.
\end{abstract}

Keywords: elasmobranchs; endemic species; Mediterranean Sea; trophic ecology; stable isotopes; stomach content 


\section{Introduction}

Identifying the trophic ecology of marine predators is necessary to defining their ecological role in ecosystems (Coll et al., 2013; Ferretti et al., 2013). Based on their trophic habits, sharks and batoids are place at higher trophic positions within the marine food webs, although differences in the main feeding strategies exist between species (Barría et al. 2015; Wetherbee et al., 2004; Cortés, 1999). However, trophic information for most elasmobranch species, in special for demersal species, is scarce (Cortés, 1999). In comparison to sharks, batoids usually receive less attention in research (Gallagher et al., 2012; Barría et al. 2015); quantitative dietary information is available for few of all existing batoids, and for the majority of these species, this information comes from only a single study (Eber and Bizzarro, 2007; Jacobsen and Bennett, 2013)

Despite the fact that the Mediterranean Sea hosts a rich fauna of batoids and is considered a hotspot of diversity of elasmobranchs (Malak et al., 2011; Dulvy et al., 2014), studies focused on describing the trophic habits of batoids are rare for particular species (e.g. Valls et al., 2011; Barría et al., 2015). Nevertheless, this region has been described as one of the most dangerous areas for these marine predators (Malak et al., 2011) due to threats associated with human activities such bottom-trawler and gill net fishing activity (Coll et al., 2012), and more than half of the batoids described in the Mediterranean Sea are in peril (Dulvy et al., 2016). While none of them are the target species of fisheries, many are captured incidentally in the Mediterranean Sea. This risk appears to be greater in the western basin, where human impact associated to fishing mortality is high (Coll et al., 2013). Consequently, there is a necessity to improve the basic ecological knowledge of these marine predators inhabiting this marine basin, including a better understanding of their trophic preferences (Ferretti et al., 2013).

Speckled ray (Raja polystigma Regan, 1923) is one of the three endemic batoids in the Mediterranean waters (Serena et al., 2005; Dulvy et al., 2016). This species is a small demersal batoid present in continental shelf habitats characterized by the presence of sand or mud, mainly at depths between 100-400 m (Serena et al. 2005; Ungaro et al., 2015). Although R. polystigma is considered as Least Concern by the International Union for Conservation of Nature (IUCN), the information available about its basic ecology is very scarce (Ungaro et al., 2015; Porcu et al. 2020). Its distribution overlaps in areas of intense trawling, and thus it is frequently captured as bycatch in the western Mediterranean (Ungaro et al., 2015). Moreover, fisheries negatively affect the target species of an ecosystem but also non-target species, normally reducing the abundance of large predators but increasing the number of small prey (Daan et al., 2005). Thus, knowing the diet of each species in an ecosystem is of vital importance to evaluate the impact of fishing activities. However, non-target species such as $R$. polystigma are usually not a subject of research due to their lack of economic value (Pope et al., 2000), and the trophic information about $R$. polystigma is currently only based on a few unspecific studies. These studies indicated 
that the diet of $R$. polystigma is mainly based on crustaceans (Vannucci et al., 2006; Valls et al., 2011), particularly of Natantia decapods (Valls et al., 2011), but teleosts, cephalopods, polychaetes and isopods, among others, have also been recorded in R. polystigma stomachs (Vannucci et al., 2006; Valls et al., 2011, Barría et al., 2015).

The study of the diet of marine predators is commonly determined through the analysis of stomach contents (Hyslop, 1980). While this methodology allows high levels of taxonomic prey resolution, batoids often have empty stomachs and the prey present in the stomachs are often skewed towards those that are difficult to digest (Hyslop, 1980; Vaudo and Heithaus, 2011; Kim et al., 2012). In addition, stomach content analyses require large sample sizes to quantify longterm dietary patterns (Hyslop, 1980; Cortes, 1999), which are difficult to achieve for most species of elasmobranchs (Stergiou and Karpouzi, 2002; MacNeil et al., 2005). The analysis of stable isotopes of nitrogen $\left(\delta^{15} \mathrm{~N}\right)$ and carbon $\left(\delta^{13} \mathrm{C}\right)$, and isotopic mixing models have been used as complementary tools to investigate time-integrated dietary records of marine predators (Shiffman et al., 2012; Kim et al., 2012; Layman et al., 2012). For example, stable isotopic values in elasmobranch muscle reflect long-term dietary information $(\sim 1$ year; MacNeil et al., 2005; Logan and Lutcavage, 2010). The combination of stomach content and isotopic analyses is valuable for a better understanding of the trophic ecology of marine organisms (Shiffman et al., 2012).

In the present study, we examined the trophic ecology of $R$. polystigma in the western Mediterranean Sea using a combined approach of stomach contents and stable isotopes (nitrogen and carbon isotopic values) in muscle tissue. We then compared trophic niche and trophic level with published trophic information on other sympatric batoids present in the ecosystem. Our study provides new information about the ecological role of $R$. polystigma within the marine ecosystems, offering new data on how this demersal predator exploits available resources.

\section{Material and Methods}

\subsection{Study area and sampling procedures}

This study was carried out in the north-western Mediterranean Sea (Fig. 1). The Mediterranean Sea is considered as an oligotrophic sea due mainly to the loss of nutrientenriched waters to the Atlantic through the Gibraltar Strait (Estrada, 1996). However, the northwestern Mediterranean waters are characterized by the presence of the Liguro-ProvençalCatalan Current that follows the continental shelf towards the west and south according to the geostrophic equilibrium. This, combined with the winter disruption of the thermocline and the river discharge of the Ebro and other rivers, causes a huge input of nutrients to the superficial layers of the Catalan Sea (Salat, 1995; Estrada, 1996). 
Between 2015 and 2018, a total of 47 mature R. polystigma individuals were captured opportunistically as by-catch during commercial fishing operations of a hake trawl fishery at 125-145 m depth in a fishing management area of $51 \mathrm{~km}^{2}$ (LLUS project; Institut de Ciències del Mar-CSIC; Figure 1). After collection, all individuals were frozen at $-20^{\circ} \mathrm{C}$ until their dissection. In the laboratory, from each collected individual, we measured the body weight $( \pm 1$ $\mathrm{g})$, the total body length $( \pm 0.1 \mathrm{~cm})$, the anal length $( \pm 0.1 \mathrm{~cm})$, and the disk width $( \pm 0.1 \mathrm{~cm})$. The stomach and a small portion of dorsal muscle (without skin or cartilage) were extracted from each specimen and stored at $-20^{\circ} \mathrm{C}$ until analysis. All collected individuals were mature based on their total body length ( $>40-53 \mathrm{~cm}$ was considered mature; see Serena et al., 2005; Ungaro et al., 2015).

\subsection{Stomach content analysis}

At the laboratory, each stomach was weighed and its contents were extracted. Prey items found in each stomach were separated and identified to the lowest taxonomic level possible and weighed. We did not consider prey items found in the mouth to avoid a potential bias derived from the possible capture in the trawling net. Whenever fragments were observed, the number of individuals was registered as the smallest number so as not to overestimate the occurrence of prey items. Teleost prey were identified by combining visual identification directly or by their otoliths (Tuset et al. 2008). Crustacean prey were identified using the reference guide of Zariquiey-Alvarez (1986).

To assess the importance of different prey in the diet, we calculated three trophic metrics: $\% \mathrm{FO}$ (frequency of occurrence), $\% \mathrm{~N}$ (contribution by number of each prey) and \%W (wet weight of each prey). Moreover, the \%IRI (percentage of the index of relative importance; Pinkas, 1971; Cortés, 1997) of each prey $i$ in the diet of $R$. polystigma was also calculated: $\% \mathrm{IRI}_{i}=\% \mathrm{FO}_{i} \cdot\left(\% \mathrm{~N}_{i}+\% \mathrm{~W}_{i}\right)$

All calculations were based on the number of non-empty stomachs. The vacuity index, $\% \mathrm{~V}=$ percentage of empty stomachs, was also calculated.

\subsection{Stable isotope analysis}

Muscle samples were dried, powdered, urea extracted and 0.28-0.33 mg of each sample was packed into tin capsules. Isotopic analyses were performed at the Laboratory of Stable Isotopes of the Estación Biológica de Doñana (LIE-EBD, Sevilla, Spain). Encapsulated samples were combusted at $1020^{\circ} \mathrm{C}$ using a continuous flow isotope-ratio mass spectrometry system by means of a Flash HT Plus elemental analyser coupled to a Delta-V Advantage isotope ratio mass spectrometer via a CONFLO IV interface (Thermo Fisher Scientific). The isotopic composition is reported in the conventional delta $(\delta)$ per mil notation (\%), relative to Vienna Pee Dee Belemnite $\left(\delta^{13} \mathrm{C}\right)$ and atmospheric $\mathrm{N}_{2}\left(\delta^{15} \mathrm{~N}\right)$. Replicate assays of standards routinely inserted 
within the sampling sequence indicated analytical measurement errors of $\pm 0.1 \%$ and $\pm 0.2 \%$ for $\delta^{13} \mathrm{C}$ and $\delta^{15} \mathrm{~N}$, respectively. The standards used were EBD-23 (cow horn, internal standard), LIE-BB (whale baleen, internal standard) and LIE-PA (razorbill feathers, internal standard). These laboratory standards were previously calibrated with international standards supplied by the International Atomic Energy Agency (IAEA, Vienna). Urea content was removed from the muscle samples placing them in scintillation vials and rinsed three times in $10 \mathrm{~mL}$ of de-ionized water (Kim and Koch 2012). The C:N ratio of all tissues was always lower than $3.5 \%$, and hence, no correction of the $\delta^{13} \mathrm{C}$ values was required to account for the presence of lipids in muscle samples (Logan et al. 2008).

\subsection{Comparison of the trophic position with other sympatric batoid species}

To understand the ecological role of R. polystigma in relation to other batoid species in the ecosystem we compared its trophic position (based on the isotopic values) with published isotopic information of Myliobatiformes (Gymnura altavela, Myliobatis aquila, Mobula mobular), Rajiformes (Dipturus oxyrinchus, Leucoraja naevus, Raja asterias, Raja clavata, Raja montagui, Raja polystigma) and Torpediniformes (Torpedo marmorata, Torpedo nobiliana, Torpedo torpedo) present in the study area (from Barría et al. 2015).

\subsection{Statistical analyses}

Stomach content differences $(\% \mathrm{~W})$ were analysed applying semi-parametric permutation multivariate analyses of variance tests (PERMANOVA tests). Also, we compared the stable isotopic values between sexes by using Student's T tests.

To estimate the diet composition of $R$. polystigma based on isotopic values,MixSIAR Bayesian isotopic mixing model was applied (Stock and Semmens, 2016). Models were run with a generalist type prior, 3 Markov chain Monte Carlo (MCMC) chains of 300,000 draws and a burn-in of 200,000 draws. The convergence of models was checked using both GelmanRubin and Geweke diagnostics (Stock and Semmens, 2016; Stock et al., 2018). To run the MixSIAR model, potential preys were selected in accordance with the information obtained from the stomach content analysis, namely Natantia $\left(\delta^{15} \mathrm{~N}: 7.82 \pm 0.66 ; \delta^{13} \mathrm{C}:-19.39 \pm 0.90\right)$, Reptantia $\left(\delta^{15} \mathrm{~N}: 7.18 \pm 0.52 ; \delta^{13} \mathrm{C}:-16.08 \pm 1.80\right)$ and teleosts $\left(\delta^{15} \mathrm{~N}: 8.61 \pm 0.93 ; \delta^{13} \mathrm{C}:-19.50 \pm\right.$ $0.80)$. Isotopic values of potential prey used were obtained from an isotopic library containing 128 species captured in the study area (IsoLibrary Database; Institut de Ciències del Mar CSIC; Barría et al. 2015). ANOVA and Tukey post-hoc tests indicated that these three prey groups differed in their $\delta^{15} \mathrm{~N}$ values (teleost showed higher $\delta^{15} \mathrm{~N}$ values than Natantia and Reptantia; $F=3.54, \mathrm{p}<0.001$ ) and $\delta^{13} \mathrm{C}$ values (Reptantia showed higher $\delta^{13} \mathrm{C}$ values than Natantia and teleosts; $F=-2.72, \mathrm{p}<0.001)$. 
The accurate use of isotopic mixing models is always limited by the correct knowledge and application of the diet tissue discrimination factors of $\delta^{15} \mathrm{~N}\left(\Delta^{15} \mathrm{~N}\right)$ and $\delta^{13} \mathrm{C}\left(\Delta^{13} \mathrm{C}\right)$ and (see Bond and Diamond 2011; Phillips et al. 2014). Different diet tissue discrimination factors have been previously used in other studies dealing with elasmobranch muscle (e.g. Hussey et al. 2009, 2010; Tilley et al. 2013). Here, because no specific discrimination factor for $R$. polystigma is available, we applied the combination of different diet tissue discrimination factors used in other elasmobranchs to obtain an overall picture of the potential prey contributions as a result of varying DTDF (Tilley et al. 2013; Albo-Puigserver et al. 2015). Specifically, we used three combinations of diet-tissue-discrimination factor values of $\Delta \Delta^{15} \mathrm{~N}=1.95 \pm 0.26 \%$ and $\Delta \Delta^{13} \mathrm{C}=0.49 \pm 0.32 \%$ (Hussey et al. 2010 ), $\Delta^{15} \mathrm{~N}=3.39 \pm 3.03 \%$ and $\Delta{ }^{13} \mathrm{C}=-0.22 \pm 2.33 \%$ (Tilley et al. 2013) and $\Delta{ }^{15} \mathrm{~N}=2.29 \pm 0.22 \%$ and $\Delta{ }^{13} \mathrm{C}=0.90 \pm 0.33 \%$ (Hussey et al. 2009).

\section{Results}

\subsection{Diet composition based on stomach contents}

All of the 47 stomachs analysed presented contents; hence, the vacuity index was $0 \%$. The results of the stomach content analysis showed that the diet of R. polystigma was similar between sexes (Tables 2 and 3; PERMANOVA tests, pseudo-F $=3.43$, $\mathrm{p}=0.002$; pairwise tests, pseudo-T $=1.08, \mathrm{p}=0.11)$. Specifically, based on the stomach content results the diet of this ray was mainly based on decapods of the suborder Natantia, although many other prey from different taxonomic groups were also found (Table 2). Within the group Natantia, the presence of Solenocera membranacea and especially Processa sp. were particularly important, although the highest \%IRI was obtained from unidentified Natantia individuals (Table 2). The suborder Reptantia was also important because of the number of species found (Goneplax rhomboides, Liocarcinus depurator and Monodaeus couchii), yet the weight and number of individuals were lower than prey of the group Natantia (Table 2). We also found species of teleosts (Argentina sphyraena, Merluccius merluccius and Trisopterus minutus), polychaetes (Aphrodita sp.) and a cephalopod (Illex coindetii). The presence of small embryos of the demersal shark Scyliorhinus canicula, found in two different stomachs (see SM1). Many stomachs also contained material of anthropogenic origin (Table 2).

\subsection{Stable isotopes}

We did not find isotopic differences $\left(\delta^{13} \mathrm{C}\right.$ and $\left.\delta^{15} \mathrm{~N}\right)$ between males and females (Table 1). Isotopic mixing models showed that the diet of R. polystigma is primarily composed of the 
Natantia crustaceans $($ mean $=86-97 \%)$, followed by Reptantia crustaceans $($ mean $=5-10 \%)$ and teleosts (mean $=2-4 \%$; Fig. 2).

\subsection{Comparison of the trophic position with other sympatric batoid species}

When comparing the isotopic values of $R$. polystigma with those of other sympatric batoid species in the study area, we found that $R$. polystigma has similar isotopic values to other batoids such as L. naevus or Dipturus oxyrinchus but with a higher trophic position based on their $\delta^{15} \mathrm{~N}$ values (Fig. 3). Nevertheless, the trophic position based on the $\delta^{15} \mathrm{~N}$ values of $R$. polystigma is lower than those of batoids from the family Torpedinidae such as Torpedo torpedo (Fig. 3).

\section{Discussion}

Determining the biological and ecological characteristics of marine species, and concretely of vulnerable and endangered species, is of vital importance to understand their trophic or ecological role in the environment. Batoids can play significant ecological roles in the marine food webs due to their abundance and species diversity (Gallagher et al., 2012; Barría et al. 2015). In the case of $R$. polystigma, the few studies conducted on this species and the probable confusion with other batoid species such as $R$. montagui (Serena et al., 2005) contribute to the scarcity of available information about basic aspects of R. polystigma ecology. For this reason, the information presented in this paper could be useful to complement the little existing data on this species, endemic to the Mediterranean Sea.

With the combination of two complementary techniques, stomach content analysis and stable isotope analysis, we have described the diet of R. polystigma. Stomach content analysis provides short-term trophic information whereas stable isotopes allow us to obtain long-term information, although the taxonomic resolution is lower (Hyslop, 1980; Shiffman et al., 2012). Both methodologies indicate that the diet of $R$. polystigma is primarily composed of Natantia crustaceans. This reconfirms the results obtained in previous studies (Valls et al., 2011; Barría et al., 2015), albeit in this study the contribution of Natantia to the diet of $R$. polystigma showed higher IRI\% values. The presence of Processa sp. and Solenocera membranacea in the diet suggests that $R$. polystigma capture these prey from their dens in the sediment. These two crustacean species inhabit soft bottoms also occupied by $R$. polystigma and are notably abundant in the Catalan Sea, with maximum abundances at depths of 200-400 m (Abelló et al., 1988). Thus, $R$. polystigma, which is distributed at these depths, would have easy access to these resources. The next groups in terms of importance in the diet are the Reptantia crustaceans and teleosts. Many of the teleosts found in the stomachs of $R$. polystigma were only partial specimens due to digestive activity, and in some cases we only found otoliths; thus, the 
importance in weight of this group may be slightly higher. In much lower proportions, we obtained other prey such us polychaetes and cephalopods, but the most surprising prey was the embryos of the demersal shark Scyliorhinus canicula (see SM1) This is the first time that a chondrichthyan has been described in the diet of R. polystigma. The fact that this species was found in two different stomachs would indicate that it is not an isolated event. $S$. canicula is the most abundant demersal shark in the Mediterranean Sea (Compagno, 1984; Navarro et al. 2016; Barría et al., 2018). Moreover, this is an oviparous species that lays eggs year-round in soft bottoms (Compagno, 1984) frequented by R. polystigma. All of these characteristics suggest that embryos of $S$. canicula could be an easy-access prey for $R$. polystigma.

Knowing the trophic niche of elasmobranchs is useful to understand their ecological role in relation to other species in the marine ecosystem (Cortés, 1999; Barría et al., 2015). By comparing the trophic niche of $R$. polystigma with those of other sympatric batoid species of the Mediterranean, we observed that this ray showed similar values than other Mediterranean batoids with a crustacean-based diet habits. However, in the present study the isotopic values of this ray is different than the results published previously in the study area, in which $R$. polystigma showed similar values than Mobula mobular (Barría et al., 2015). This is probably because the individuals in the current study had a greater total mean length, and consequently larger mouths. In fact, three of the individuals captured in this study exceeded the maximum total length of $60 \mathrm{~cm}$ described previously for R. polystigma (Serena et al., 2005; Ungaro et al., 2015), reaching $63.1 \mathrm{~cm}$. Larger sizes were detected in females, as many of them had larger gonads or even capsules. As previously noted in other batoid species, an increase in corporal size provokes changes in the contribution of different prey species or different size of the prey to the diet (White et al., 2004), consequently altering the trophic niche.

In conclusion, this study provides new information about the trophic ecology of $R$. polystigma in the north-western Mediterranean Sea and complements the knowledge described in previous studies. The two methodologies used indicated the great importance of Natantia crustaceans to the diet of R. polystigma and the lack of feeding differences between sexes. Furthermore, this study confirms the great benefits of combining two complementary methodologies like stomach content and stable isotope analyses with the purpose of studying the trophic ecology of batoids and other chondrichthyans. We strongly recommend further studies about the trophic ecology of $R$. polystigma in other Mediterranean areas and with immature individuals to analyse potential differences, due to the fact that batoids occupy several habitats throughout their life, generating variations in their ecological role depending on location, sex, size and availability of prey.

\section{Acknowledgements}

We acknowledge the fishermen from Roses for helping us with the sample collection and the 
project LLUS (Institut de Ciències del Mar, CSIC), for making these campaigns possible. Special thanks to Pere Abelló and Antoni Lombarte for helping with taxonomic identification and David Nos for his support in the laboratory work. EC-C was funded by a Student Travel Bursaries grant of the European Elasmobranch Association to present the results of this paper at the EEA Annual Scientific Meeting 2018 in Peniche (Portugal). JN was funded by the Spanish National Program Ramón y Cajal (RYC-2015-17809). This study is a contribution to the project RESNEP (CTM2017-82991-C2-1-R, Ministry of Science and Innovation, Spain). We declare that all experimental procedures were conducted in strict accordance with good animal practice as defined by the current Spanish, Catalonian and European legislation.

\section{References}

Abelló, P., Valladares, F.J., Castellón, A., 1988. Analysis of the structure of decapod crustacean assemblages off the Catalan coast (North-West Mediterranean). Marine Biology 98, 39-49

Albo-Puigserver, M., Navarro, J., Coll, M., Aguzzi, J., Cardona, L., Sáez-Liante, R., 2015. Feeding ecology and trophic position of three sympatric demersal chondrichthyes in the Northwestern Mediterranean. Marine Ecology Progress Series 524, 255-268

Barría, C., Coll, M., Navarro, J., 2015. Unravelling the ecological role and trophic relationships of uncommon and threatened elasmobranchs in the western Mediterranean Sea. Marine Ecology Progress Series 539, 225-240

Barría, C., Navarro, J., Coll, M., 2018. Trophic habits of an abundant shark in the northwestern Mediterranean Sea using an isotopic non-lethal approach. Estuarine, Coastal and Shelf Science 207, 383-390

Bond, A. L., Diamond, A. W., 2011. Recent Bayesian stable-isotope mixing models are highly sensitive to variation in discrimination factors. Ecological Applications 21, 1017-1023

Coll, M., Navarro, J., Palomera, I., 2013. Ecological role, fishing impact, and management options for the recovery of a Mediterranean endemic skate by means of food web models. Biological Conservation 157, 108-120

Compagno, L.J.V., 1984. FAO species catalogue. Vol. 4, Part 1; Sharks of the world. FAO Fish Synop, 125, 416-417.

Cortés, E., 1997. A critical review of methods of studying fish feeding based on analysis of stomach contents: application to elasmobranch fishes. Canadian Journal of Fisheries and Aquatic Sciences 54, 726-738

Cortés, E., 1999. Standardized diet compositions and trophic levels of sharks. ICES Journal of Marine Science, 56, 707-717

Daan, N., Gislason, H., G. Pope, J., Rice, J., 2005. Changes in the North Sea fish community: evidence of indirect effects of fishing?.ICES Journal of Marine Science, 62, 177-188. 
Dulvy, N.K., Fowler, S.L., Musick, J.A., Cavanagh, R.D., Kyne, P.M., Harrison, L.R., ... and Pollock, C.M., 2014. Extinction risk and conservation of the world's sharks and rays. Elife 3, e00590

Dulvy, N.K., Allen, D.J., Ralph, G.M., Walls, R.H.L., 2016. The conservation status of Sharks, Rays and Chimaeras in the Mediterranean Sea [Brochure]. IUCN, Malaga, Spain

Ebert, D. A., Bizzarro, J.J. (2007). Standardized diet compositions and trophic levels of skates (Chondrichthyes: Rajiformes: Rajoidei). Biology of Skates. Springer, Dordrecht, 115-131.

Estrada, M., 1996. Primary production in the northwestern Mediterranean. Scientia Marina, 60, $55-64$

Ferretti, F., Osio, G.C., Jenkins, C.J., Rosenberg, A.A., Lotze, H.K., 2013. Long-term change in a meso-predator community in response to prolonged and heterogeneous human impact.

Scientific Reports 3, 1057

Gallagher, A.J., Kyne, P.M., Hammerschlag, N., 2012. Ecological risk assessment and its application to elasmobranch conservation and management. Journal of Fish Biology 80, $1727-1748$

Hussey, N.E., Brush, J., McCarthy, I.D., Fisk, A.T., 2010. $\delta^{15} \mathrm{~N}$ and $\delta^{13} \mathrm{C}$ diet-tissue discrimination factors for large sharks under semi-controlled conditions. Comparative Biochemistry and Physiology Part A: Molecular and Integrative Physiology 155, 445-453

Hyslop, E.J., 1980. Stomach content analysis: a review of methods and their application. Journal of Fish Biology 17, 411-429

Jacobsen, I.P., Bennett, M.B. 2013. A comparative analysis of feeding and trophic level ecology in stingrays (Rajiformes; Myliobatoidei) and electric rays (Rajiformes: Torpedinoidei). PLoS ONE 8.8, e71348.

Kim, S.L., Casper, D.R., Galván-Magaña, F., Ochoa-Díaz, R., Hernández-Aguilar, S. B., Koch, P.L., 2012. Carbon and nitrogen discrimination factors for elasmobranch soft tissues based on a long-term controlled feeding study. Environmental Biology of Fishes 95, 37-52

Kim, S.L., Koch, P.L. 2012. Methods to collect, preserve, and prepare elasmobranch tissues for stable isotope analysis. Environmental Biology of Fishes 95, 53-63

Layman, C.A., Araujo, M.S., Boucek, R., Hammerschlag-Peyer, C.M., Harrison, E., Jud, Z.R., ... Post, D.M., 2012. Applying stable isotopes to examine food web structure: an overview of analytical tools. Biological Reviews 87, 545-562

Logan, J.M., Jardine, T.D., Miller, T.J., Bunn, S.E., Cunjak, R.A., Lutcavage, M.E. (2008) Lipid corrections in carbon and nitrogen stable isotope analyses: comparison of chemical extraction and modelling methods. Journal of Animal Ecology 77:838-846

Logan, J.M., Lutcavage, M.E., 2010. Stable isotope dynamics in elasmobranch fishes. Hydrobiologia 644, 231-244 
MacNeil, M.A., Skomal, G.B., Fisk, A.T., 2005. Stable isotopes from multiple tissues reveal diet switching in sharks. Marine Ecology Progress Series 302, 199-206

Malak, D.A., 2011. Overview of the conservation status of the marine fishes of the Mediterranean Sea. IUCN.

Navarro, J., Coll, M., Preminger, M., Palomera, I., 2013. Feeding ecology and trophic position of a Mediterranean endemic ray: consistency between sexes, maturity stages and seasons. Environmental Biology of Fishes 96, 1315-1328

Pinkas, L., 1971. Food habits study. Fish Bulletin 152, 1-105.

Pope, J.G., Macdonald, D.S., Daan, N., Reynolds, J.D., Jennings, S., 2000. Gauging the impact of fishing mortality on non-target species. ICES Journal of Marine Science 57, 689-696.

Porcu, C., Bellodi, A., Cau, A., Cannas, R., Marongiu, M. F., Mulas, A., Follesa, M. C., 2020. Uncommon biological patterns of a little known endemic Mediterranean skate, Raja polystigma (Risso, 1810). Regional Studies in Marine Science, 101065.

Ramirez, F., Coll, M., Navarro, J., Bustamante, J., Green, A.J., 2018. Spatial congruence between multiple stressors in the Mediterranean Sea may reduce its resilience to climate impacts. Scientific Reports 8, 14871

Šantić, M., Rađa, B., Pallaoro, A., 2012. Diet and feeding strategy of thornback ray Raja clavata. Journal of Fish Biology 81, 1070-1084

Salat, J., 1995. The interaction between the Catalan and Balearic currents in the southern Catalan Sea. Oceanologica Acta 18, 227-234

Serena, F., Mancusi, C., Barone, M., Abella, J., 2005. Abundance and distribution of rays in the South Ligurian and North Tyrrhenian Sea. ICES Document CM, 20, 16.

Shiffman, D.S., Gallagher, A.J., Boyle, M.D., Hammerschlag-Peyer, C.M., Hammerschlag, N., 2012. Stable isotope analysis as a tool for elasmobranch conservation research: a primer for non-specialists. Marine and Freshwater Research 63, 635-643

Stergiou, K.I., Karpouzi, V.S., 2002. Feeding habits and trophic levels of Mediterranean fish. Reviews in Fish Biology and Fisheries 11, 217-254

Stock, B.C., Jackson, A.L., Ward, E.J., Parnell, A.C., Phillips, D.L., Semmens, B.X., 2018. Analyzing mixing systems using a new generation of Bayesian tracer mixing models. PeerJ 6, e5096

Stock, B.C., Semmens, B.X., 2016. Unifying error structures in commonly used biotracer mixing models. Ecology 97, 2562-2569

Tuset, V.M., Lombarte, A. Assis, C.A., 2008. Otolith atlas for the western Mediterranean, north and central Eastern Atlantic. Scientia Marina 72, 7-198

Ungaro, N., Dulvy, N.K., Tinti, F., Bertozzi, M., Notarbartolo di Sciara, G., Serena, F., Abella, A., Walls, R.H.L., 2015. Raja polystigma. The IUCN Red List of Threatened Species:

e.T161673A48910425, Downloaded on 16 July 2019 
Valls, M., Quetglas, A., Ordines, F., Moranta, J., 2011. Feeding ecology of demersal elasmobranchs from the shelf and slope off the Balearic Sea (western Mediterranean).

Scientia Marina 75, 633-639

Vannucci, S., Mancusi, C., Serena, F., Cuoco, C., Volani, A., 2006. Feeding ecology of rays in the southern Ligurian Sea. Biologia Marina Mediterranea 13, 296-297

Vaudo, J.J., Heithaus, M.R., 2011. Dietary niche overlap in a nearshore elasmobranch mesopredator community. Marine Ecology Progress Series 425, 247-260.

Wetherbee, B.M., Cortés, E., Bizzarro, J.J., 2004. Food consumption and feeding habits. In: Biology of Sharks and their Relatives, pp. 225-246.

White, W.T., Platell, M.E., Potter, I.C., 2004. Comparisons between the diets of four abundant species of elasmobranchs in a subtropical embayment: implications for resource partitioning. Marine Biology 144, 439-448.

Zariquiey-Alvarez, R., 1968. Crustáceos Decápodos Ibéricos. Investigación Pesquera 32, 510. 
Table 1. Mean \pm standard deviation of the different morphometric measurements and stable isotopic values of males and females of Raja polystigma from the north-western Mediterranean Sea.

\begin{tabular}{ccc}
\hline Measure & Males $(\mathrm{n}=26)$ & Females $(\mathrm{n}=21)$ \\
\hline Total Weight $(\mathrm{g})$ & $807.29 \pm 211.63$ & $1023.81 \pm 380.26$ \\
Total Length $(\mathrm{cm})$ & $52.55 \pm 3.93$ & $54.54 \pm 5.78$ \\
Anal Length $(\mathrm{cm})$ & $22.68 \pm 1.93$ & $24.49 \pm 2.98$ \\
Disk Length (cm) & $26.38 \pm 2.06$ & $27.83 \pm 3.06$ \\
Disk Width (cm) & $33.07 \pm 2.45$ & $35.43 \pm 3.67$ \\
$\delta^{15} \mathrm{~N}(\%$ oo $)$ & $10.27 \pm 0.45$ & $10.12 \pm 0.37$ \\
$\delta^{13} \mathrm{C}(\%$ oo $)$ & $-17.05 \pm 0.36$ & $-17.01 \pm 0.31$ \\
\hline
\end{tabular}

Table 2. Diet composition of Raja polystigma expressed in 
frequency of occurrence $(\% \mathrm{FO})$, frequency in number $(\% \mathrm{~N})$, wet weight $(\% \mathrm{~W})$ and Index of Relative Importance in percentage (\%IRI). $\mathrm{N}=47$ individuals.

\begin{tabular}{lcccc}
\hline \multicolumn{1}{c}{ PREY } & $\% \mathrm{~F}$ & $\% \mathrm{~N}$ & $\% \mathrm{~W}$ & $\% \mathrm{IRI}$ \\
\hline POLYCHAETA & & & & 0.01 \\
Aphrodita sp. & 2.13 & 0.41 & 0.06 & 0.01 \\
CEPHALOPODA & & & & 0.07 \\
Illex coindetii & 2.13 & 0.41 & 2.90 & 0.07 \\
NATANTIA & & & & 97.27 \\
Processa sp. & 40.43 & 25.00 & 19.00 & 18.01 \\
Solenocera membranacea & 23.40 & 6.15 & 9.30 & 3.66 \\
Unidentified & 80.85 & 57.79 & 34.54 & 75.60 \\
REPTANTIA & & & & 0.47 \\
Goneplax rhomboides & 2.13 & 0.41 & 0.71 & 0.02 \\
Liocarcinus depurator & 4.26 & 0.82 & 0.20 & 0.04 \\
Monodaeus couchii & 2.13 & 0.41 & 0.78 & 0.03 \\
Unidentified & 10.64 & 2.05 & 1.40 & 0.37 \\
TELEOSTEI & & & & 1.79 \\
Argentina sphyraena & 2.13 & 0.41 & 12.81 & 0.28 \\
Merluccius merluccius & 8.51 & 2.05 & 15.13 & 1.48 \\
Trisopterus minutus & 2.13 & 0.41 & 0.81 & 0.03 \\
CHONDRICHTHYES & & & & 0.26 \\
Scyliorhinus canicula & & & & \\
(embryos) & & & & \\
OTHERS & 6.38 & 2.46 & 1.59 & 0.26 \\
Anthropogenic content & 6.38 & 1.23 & 0.78 & 0.13 \\
\hline
\end{tabular}


Table 3. Percentage of the index of relative importance (\%IRI) of the main taxonomic groups in the diet of Raja polystigma expressed in $\% \mathrm{~F}, \% \mathrm{~N}, \% \mathrm{~W}$ and $\%$ IRI based on the sex of the individuals $(\mathrm{N}$ males $=26 ; \mathrm{N}$ females $=21)$.

\begin{tabular}{lcc}
\hline \multicolumn{1}{c}{ PREY } & Males $(\mathrm{n}=26)$ & Females $(\mathrm{n}=21)$ \\
\hline Cephalopoda & 0.35 & 0.03 \\
Natantia & 95.51 & 97.44 \\
Reptantia & 0.73 & 0.50 \\
Teleostei & 2.80 & 1.70 \\
Chondrichthyes & 0.55 & 0.11 \\
Anthropogenic content & 0.06 & 0.21 \\
\hline
\end{tabular}


Fig. 1. Study area and sampling location (white square) in the Catalan Sea, north-western Mediterranean.

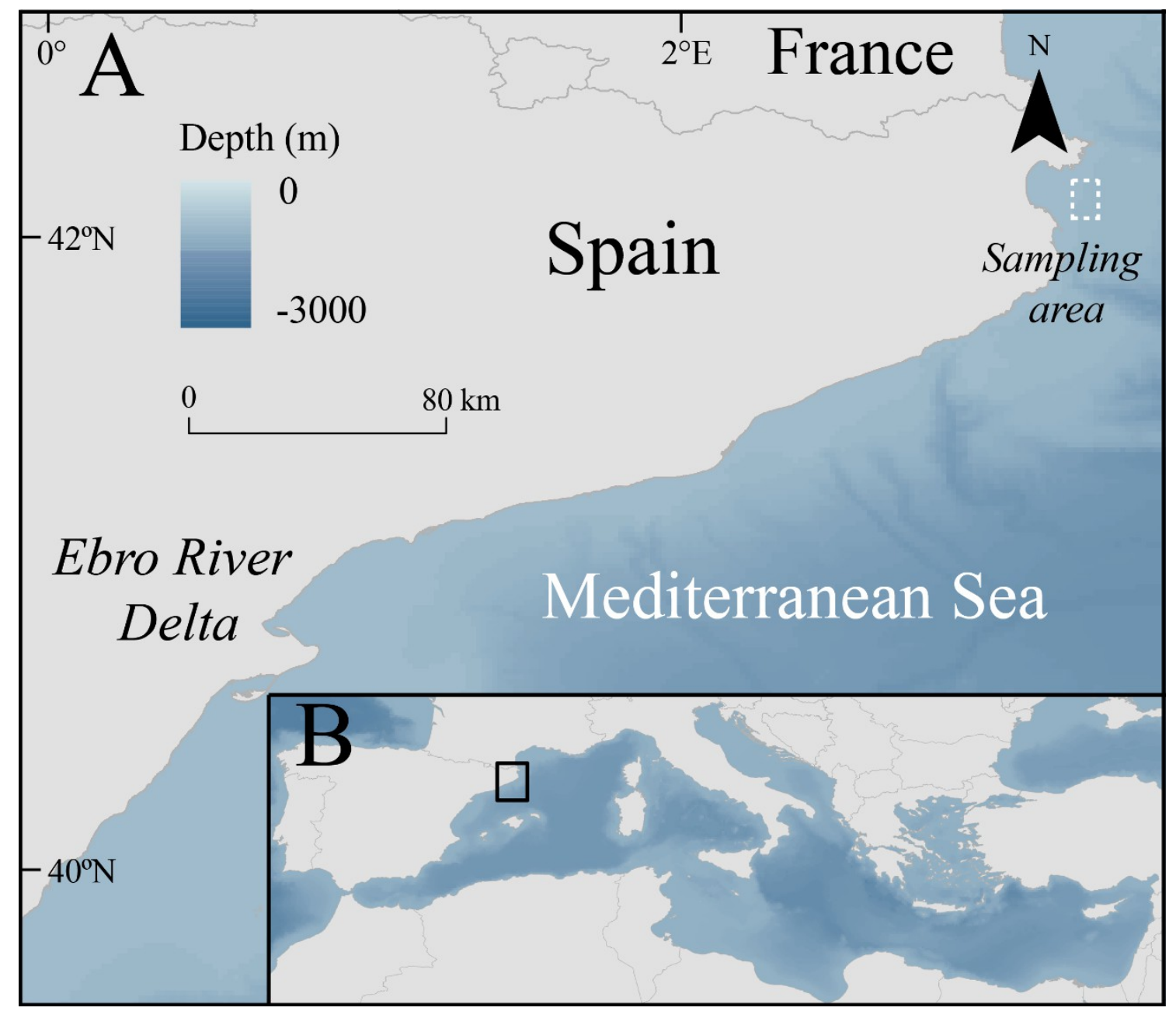


Fig. 2. Results of the MixSIAR model showing estimated prey group contributions to the diet of Raja polystigma using three combinations of diet-tissue discrimination factors DTDF $(\mathrm{C} 1$ :

$\Delta \Delta^{15} \mathrm{~N}=1.95 \pm 0.26 \%$, $\Delta \Delta^{13} \mathrm{C}=0.49 \pm 0.32 \%$, Hussey et al. $2010 ; \mathrm{C} 2: \Delta^{15} \mathrm{~N}=3.39 \pm 3.03 \%$, $\Delta^{13} \mathrm{C}=$ $-0.22 \pm 2.33 \%$, Tilley et al. 2013; $\mathrm{C} 3: \Delta^{15} \mathrm{~N}=2.29 \pm 0.22 \%, \Delta^{13} \mathrm{C}=0.90 \pm 0.33 \%$, Hussey et al. 2009.

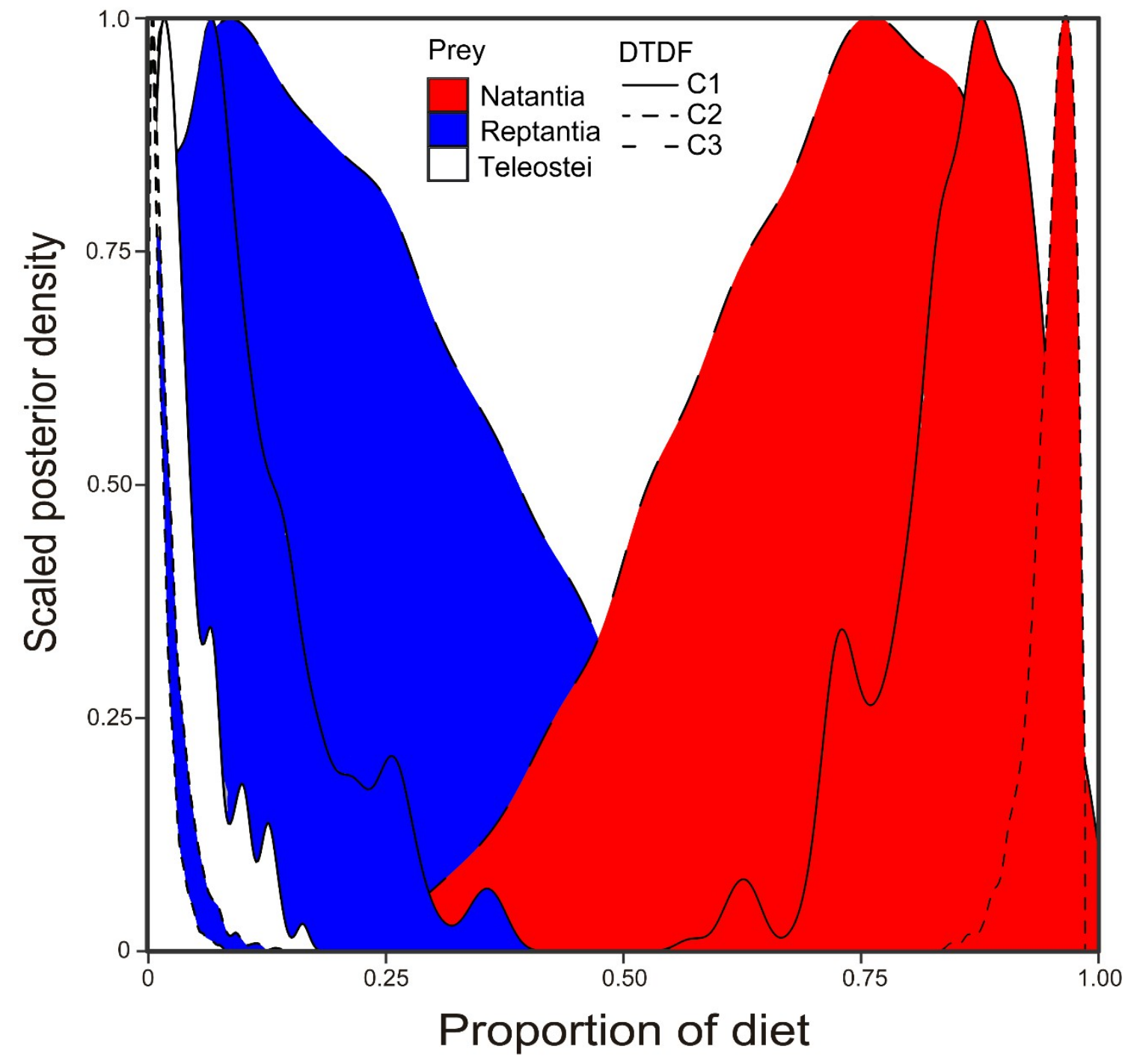


Fig. 3. Mean and standard deviation of $\delta^{15} \mathrm{~N}$ and $\delta^{13} \mathrm{C}$ values for the batoid community of the north-western Mediterranean: Myliobatiformes (Galt: Gymnura altavela, Maqu: Myliobatis aquila, Mmob: Mobula mobular), Rajiformes (Doxy: Dipturus oxyrinchus, Lnae: Leucoraja naevus, Rast: Raja asterias, Rcla: Raja clavata, Rmon: Raja montagui, Rpol: Raja polystigma) and Torpediniformes (Tmar: Torpedo marmorata, Tnob: Torpedo nobiliana, Ttor: Torpedo torpedo). Isotopic data from all batoid species expect $R$. polystigma was extracted from Barría et al. (2015).

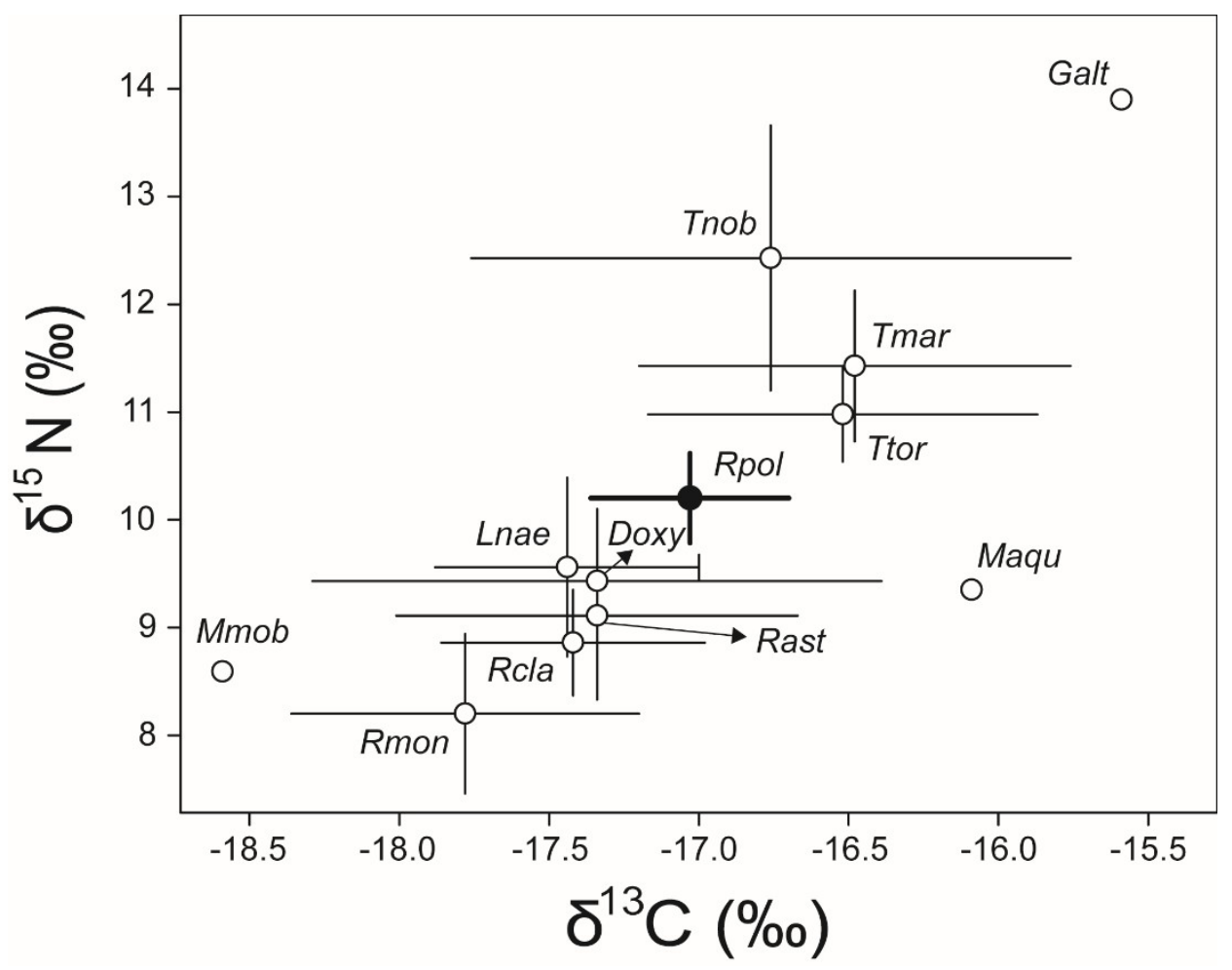

